\title{
Ademfrequentie via de app
}

Jan-Arie van Wijngaarden

In de tweede lijn is de ademfrequentie vaststellen een fluitje van een cent: een getal op de monitor. In de eerste lijn zijn we vaak aangewezen op het gewone tellen. Kan de smartphone een hulpmiddel zijn?

De ademfrequentie is een belangrijk onderzoek binnen de $\mathrm{ABCDE}-$ benadering ${ }^{1}$ en is onderdeel van verschillende scores, zoals de quick Sepsis Related Organ Failure Assessment (qSOFA) bij sepsis. ${ }^{2}$ Bij het triagesysteem Professional Quality Assurance (ProQA), dat veel meldkamers van de ambulance gebruiken, kan de centralist met behulp van de omstanders de ademhaling registreren. Het zou de moeite waard zijn om in het NTS-systeem, dat de huisartsenposten gebruiken, deze optie in te bouwen. In de ambulance wordt de ademfrequentie gemeten door de registratie van de beweging van de ecg-elektroden, of met een $\mathrm{CO}_{2}$-sensor in de uitademingslucht. De huisarts moet het echter doen met lichamelijk onderzoek. Bij de eerste benadering van de patiënt kun je een globale indruk van de ademhaling krijgen door te kijken of het interval tussen twee ademhalingen korter is dan drie seconden. In dat geval is de frequentie boven de twintig, wat bij volwassenen op pathologie kan duiden. Je telt 'eenentwintig, tweeëntwintig, drieëntwintig. Meer dan twee ademhalingen in drie seconden is zeker een indicatie voor verder onderzoek in de tweede benadering. Dan moet altijd de exacte frequentie vastgelegd worden, ook om het beloop te registreren.

\section{SMARTPHONE}

Bij ademhaling tellen is het essentieel dat de patiënt zich er niet van bewust is dat je de ademhaling telt. De leerboeken schrijven voor dat men meet 'terwijl men doet alsof men de pols telt. ${ }^{3}$ Er zijn belemmerende factoren: een pratende patiënt, kleding die in de weg zit, of een hoestbui. Om meetfouten te vermijden, tel je minimaal dertig seconden. Het is voor de dokter bij een benauwde patiënt soms moeilijk om dertig seconden 'niets te doen'. Een huisartsenpostchauffeur kan helpen. De smartphone heeft functies die hem van de gewone telefoon onderscheiden. Kunnen die ons helpen? Philips had de Vital Signs App (betaald, Apple). De camera registreerde kleur en bewegingen van het gelaat en gaf zo een adem- en hartfrequentie op het scherm. De app werkt nog steeds, maar is niet meer te koop. De Cardio Respiratory Monitor Pro (betaald, Android) heeft een bewegingssensor die de ademhaling registreert en een microfoon die de hartslag telt. De smartphone moet dan op de thorax van de liggende patiënt gelegd worden. De meeste benauwde patiënten liggen niet en het vraagt veel tijd een enigszins betrouwbare registratie te krijgen.

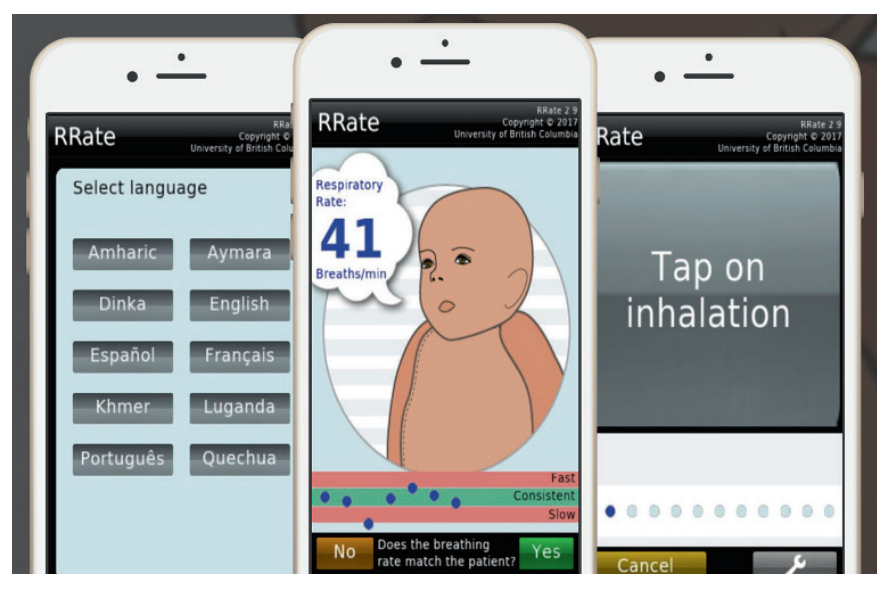

Een app kan de huisarts helpen om de ademfrequentie te tellen.

\section{TIK-APPS}

Apps die gebruikmaken van de bewegingssensor of microfoon, zijn volgens gebruikers niet betrouwbaar. Ook zijn er apps die op basis van het interval tussen twee ademhalingen een frequentie kunnen berekenen. Deze tik-apps werken hetzelfde als de genoemde module in ProQA. Voorbeelden zijn Taprate ${ }^{4}$ (gratis, Apple) en RRate (gratis, Android en Apple). De Taprate kan ingesteld worden op hart- of ademfrequentie en telt dan vervolgens alles wat je tikt. De RRate is ontwikkeld door kinderartsen. ${ }^{5}$ Deze app is instelbaar op het aantal tikken (tussen de drie en de zes) en geeft in een schema de spreiding tussen de tikken aan. Is deze te groot dan weigert hij een berekening te maken waardoor hij betrouwbaarder is. Het blijft de vraag of een observatie korter dan dertig seconden verstandig is.

De ademfrequentie meten en vastleggen bij spoedpatiënten is in de tweede lijn een fluitje van een cent: in de ambulance of in het ziekenhuis sluit je de patiënt aan op bewakingsapparatuur en je leest de ademfrequentie af op op de monitor. Maar de huisarts moet ouderwets tellen en dat blijft lastig. Een app zou ons kunnen helpen. Vooral de Vital Signs Camera-app en de RRate-app gaan in de goede richting, maar de ideale app of een eenvoudig en betrouwbaar apparaat voor de eerste lijn moeten nog ontwikkeld worden.

\section{LITERATUUR}

1. Fraanje W, Mout P, In 't Veld K. Het ABCDE van de acute huisartsgeneeskunde. Huisarts Wet 2011;54:210-4.

De volledige literatuurlijst staat bij dit artikel op www.henw.org.

Van Wijngaarden JA. Ademfrequentie via de app. Huisarts Wet 2018;61[6]:75. DOl: 10.1007/s12445-018-0156-6.

Huisartsenpost Gelderse Vallei, Ede: Jan-Arie van Wijngaarden, kaderhuisarts Spoedzorg, huisarts@wijngaardennet.nl.

Mogelijke belangenverstrengeling: niets gemeld. 